\title{
Safety awareness of roadside traders in Osogbo Township, Osun State, Nigeria
}

\author{
D. S. Ogundahunsi ${ }^{1}$, S. B. Adedotun ${ }^{1} \&$ S. A. Adejuwon ${ }^{2}$ \\ ${ }^{1}$ Osun State University, Nigeria \\ ${ }^{2}$ Osun State College of Technology, Nigeria
}

\begin{abstract}
The study focuses on evaluating the safety awareness of roadside traders along the major axis of Osogbo, Osun state, Nigeria. The objectives include to identify the location where street traders operate, assess their socio-economic characteristics, identify the risks involved and determine the traders' awareness of the risks involved in their activity. A total of 278 roadside traders were selected from six clusters on the basis of streets using stratified random sampling techniques. Findings reveal that road-side trading within the CBD of Osogbo was influenced by low level of education, poverty, need for survival and by high rent value within the CBD among other factors. The study reveals a significantly high level of awareness of the risks involved such as exposure to high concentration of pollutants, exposure to hot sun and inclement weather and being hit by vehicles among others. It is recommended that a comprehensive planned alternative retail location with high connectivity and visibility be put in place, and the protection of the traders in the form government sponsored safety regulations for their operations as well as the enforcement of the existing traffic safety measures.
\end{abstract}

Keywords: roadside trading, urbanization, economic deprivation, informal sector, traffic congestion, safety awareness, coping strategy, income, safety regulation, risk.

\section{Introduction}

A visible feature along major streets of most urban centres in Nigeria especially, at the central business district (CBD) is the bustling of commercial activities involving various categories of people displaying all kinds of articles for sale. 
This act of displaying articles on the street for sale is regarded as street trading (Skinner [1]). It entails displaying wares by the roadside, carrying head pan or raising a sample of wares to the commuters while these vehicles are moving. In the process, the street traders are exposed to hazards of varying degrees, the most prominent of which is being hit by vehicles.

Work or occupational hazard refers to danger to health, limb, or life that is inherent in, or is associated with, a particular occupation, industry, or work environment. Occupational hazards include risk of accident and of contracting occupational diseases. Lu [2] observed that occupational hazards and health challenges vary by occupational sector and the specific job of the individual. Street trading has been observed as a hazardous work that has profound implication for the health of those engaged in it. Street traders in Nigeria operate in high risk and unfriendly environment, in which they are constantly exposed to hazardous conditions that most often results in bodily harm, injures and even death.

It is difficult to determine the number of street traders in a city but Adeyinka et al. [3] stated that informal economy in Nigeria accounted for a third of the 50 million labour force out of the 123.9 million people in 1999, who are actively engaged in mostly retail trading such as, the operation of front shops, stalls, kiosks, or hawking [4]. The number obviously has been increasing steadily in the face of the rapid urbanization, rising unemployment rate and unstable economic climate in the country. The boom is linked to unprecedented rapid urbanization; as the world continues to urbanize, sustainable development challenges become increasingly concentrated in cities, particularly in the lower-middle-income countries where the pace of urbanization is fastest. This has led to several global summits such as Millennium Development Goals Summits, the 2002 World Summit in Johannesburg, the 2005 La-Havana UN sustainable cities documentation of experience programme [5] and the Rio+20 United Nations Conference on Sustainable Development, 2012, where member nations pledge their commitment to good and effective governance as a means of achieving sustainable development in the cities.

According to Umahi [6], street trading is a ready attraction for dropouts from schools and traders from distressed families. In Nigeria's major cities, they remain a common sight vending various products amidst moving vehicles (Figure 3). He further noted that, the dangers associated with this risky venture are never deterrent to them. Also, there is no age or sex barrier to engagement in the vocation; that is why it is common to see both male and female children on the road-side with loads of commodities roaming all day from place to place. This study focusses on evaluating the level of awareness of the risks involved in street trading by the traders in the study area.

\section{The study area}

Osogbo metropolitan city is situated on latitude $70^{\circ} 40^{\prime} 0^{\prime \prime} \mathrm{N}$ and longitude $4^{\circ} 37^{\prime} 31^{\prime \prime} \mathrm{E}$, and latitude $7^{\circ} 45^{\prime} 0^{\prime \prime} \mathrm{N}$ and longitude $4^{\circ} 28^{\prime} 0^{\prime \prime} \mathrm{E}$ southwest of Nigeria. Due to its very rich arts and cultural heritage, the city has worldwide acclaim [7]. 
It is the capital of Osun state and it consists of two local governments which are Osogbo and Olorunda. Based on the 2006 Population Census (provisional result) Osogbo has a population of about 287,156 people and a total land area of $47 \mathrm{~km}^{2}$.

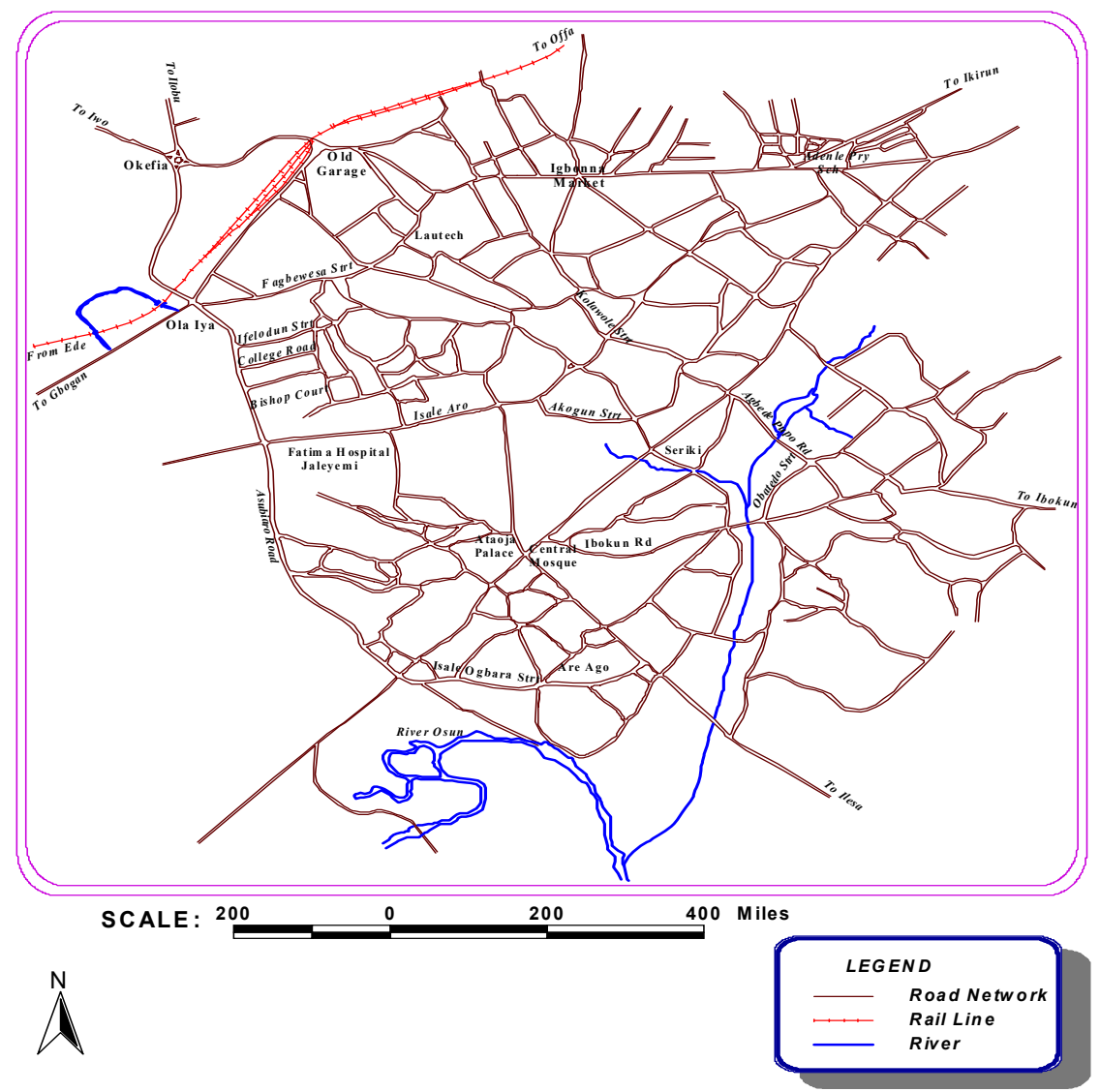

Figure 1: Transportation network of Osogbo.

As one of the regional centres of trade in the south-western part of Nigeria, the city like most cities in Nigeria can be divided into three regions; the first being the traditional core comprising the palace area, Oja-Oba (King's Market), Isale Osun and Olu-Ode districts. The intermediate region consists of Station road, Okefia, Old Garage, Ajegunle, Olaiya, Alekunwodo, Jaleyemi, Hospital road, Igbona, Ayetoro and Sabo. This region contains three major markets namely Adenle, Old Orisunmbare and New Orisunmbare, and a street market; Alekunwodo market. It witnessed remarkable growth and development in the last three decades. The Old Garage and Okefia axis has become another centre of activity due to the intensity of commercial activities aided by the 
railway station and convergence of road network. The third region which is the newly developing peripheral area comprise of Ogo-Oluwa, Halleluyah Estate, Powerline/Ota-Efun, Oke-Bale, and Dada Estate districts. The first and the second regions feature higher concentration of informal trading activities than the third especially Oja-Oba, Ajegunle, Ayetoro and Okefia areas.

\section{Concept of safety and review of literature}

Safety is the state in which the risk of harm by accident to persons or of property damage is reduced to, and maintained at or below, an acceptable level through a continuing process of hazard identification and risk management [8]. Safety is not the absence of danger or harmful situation but the effective control of such situation to ensure that it complies with situation-specific definitions of what is expected and acceptable. Hence, Oakes [9] defined safety as the control of recognized hazards to achieve an acceptable level of risk. Maintaining an acceptable level of safety requires identifying hazardous situations and taking steps towards an effective management procedure.

Several theories and concepts have been offered to explain occupational risk perception and management. The situated rationality theory is relevant to this study. It argues that there is a rational justification for why people choose to take risks as opposed to the notion of seeing risk takers as irrational or thrill-seeking. Documented cases of justified risk-taking include Keating and Halpern-Felsher [10] and Rhodes [11]. Finucane et al. [12] added that the greater the perceived benefit of an activity, the lower the perceived risk. The street traders overlook or underplay the risks involved in their activities because of the crucial need to survive unemployment and the harsh economic condition in the country. In the context of Nigerian situation, this theory could be linked to the planned behavior theory by Icek Ajcen which considers various social, environmental and psychological factors that influence a person's intention to engage in high-risk behavior $[13,14]$. The street traders have become an informal formidable group that operates in defiance of the established regulations. Cassim [14] described the informal sector participation as a trap associated with impoverishment while Habib [15] referred to it as the survivalist responses of marginalised persons with no alternative. This agrees with the contention of this study that spatial and economic deprivation resulting from unplanned urbanization engenders road-side trading in the Nigerian urban space.

Ogunrinola et al. [16] examined occupational hazards in street trading activities in Nigeria and discover that $24.6 \%$ of the traders have been injured while almost half of the respondents have experienced harassment by public authorities. Harassment suffered included bullying, beating, seizure of wares, forceful extortions and sexual overtures.

Kwankwe et al. [17] reported street trading was a source of daily livelihood for several people and a stepping-stone for preparation towards relatively better and more permanent jobs in the future. The study stated that city authorities in Accra, Ghana do embark on exercises to free the streets and pavements of hawkers, suggesting that street hawking was considered as an illegal activity. 
People outside the activity also considered it as a nuisance calling for its eradication. The study also revealed that street traders contributed to sanitation problems as they litter their operating space, accident occurrence, traffic hold-up and environmental nuisance.

Nigerian government, like some other African countries, exhibit lack of comprehension of the potentials of the informal sector and its immense contribution to the national economy. Hence, the informal economic activities such as street trading are not monitored or regulated, the public reaction has been that of antagonism. Officially, there is no regulatory policy to manage the activities of street traders and where it exists like cities of Kenya, Ghana, Zimbabwe, Cote D'Ivoire and Uganda, it is not appropriate for street vendors [18].

\section{Methodology}

Primary data for this study was acquired through structured questionnaire administered to a sample of 278 traders out of a frame of 1,023 street traders. The sample frame was disaggregated into six clusters along the major axis of the city to determine their socio-economic and demographic characteristics, the factors that contribute to their perseverance, the potentials and challenges of their activities. The data were collated with the aid of SPSS software and subjected to descriptive statistical analysis.

\section{Data presentation and analysis}

\subsection{Demographic and socio-economic characteristics of respondents}

The demographic and socio-economic characteristics considered in this study are age, gender, nativity, marital status, family size and level of education. Of the effectively sampled 278 respondents, a significant $74.5 \%$ are within the productive age bracket of $18-45$ years. $7.6 \%$ are less than 18 years while the remaining are of age 46 years and above. $60.1 \%$ of the total respondents are males and $39.9 \%$ are females. The preponderance of males is obviously due to the nature of the activity which often involve carrying their merchandise and running after customers oftentimes in moving vehicles. Only in Oja-Oba area are the genders equally represented and this evidently result from the fact that the area is occupied by a traditional market and the road is narrow. Hence, vehicles slow down while passing through, thereby reducing the stress a trader go through. This is unlike Old Garage (core) area with a lot of vehicle and pedestrian traffic where males dominate with $58.2 \%$.

The study revealed that $55.0 \%$ of the road-side traders sampled are indigenes of Osogbo; the remaining $45.0 \%$ are migrants from distant and immediate neighbouring towns. A consideration of the ethnic composition revealed that $65.3 \%$ are of Yoruba descent, 31\% of Ibo ethnic descent and 3.6\% of Hausa ethnic descent. Sixty-seven percent of the sampled population are married. Of these, a significant $42.3 \%$ has an average family size of $5,40.5 \%$ has a family 
size of 3 . Both categories constitute about $83 \%$ of the total respondents. At the extreme, $1.8 \%$ has a family size of more than 12 .

About $94 \%$ of the respondents have formal education; secondary education dominates with $52 \%$, followed by primary education with $33.5 \%$ and tertiary education with $8.7 \%$. The dominance of secondary education reveals an apparent lack of access to education beyond the secondary school, a situation which may have pushed them into street trading because of limited employment opportunities due to their level of education.

\subsection{Reasons for involvement}

Ayeni [19] attributes the cause of involvement in street trading to unemployment. While it is rational that people engage in informal activities because formal employment opportunities are not abundantly available, this study reveals that employed persons were also involved as only $32 \%$ of the respondents reported unemployment as the reason for their involvement (Table 1); it is a survival strategy for the unemployed while $2.2 \%$ reported that the activity is their primary occupation. However, $18.3 \%$ said they got involved because of the prohibitive cost of getting retail space while a significant $47.5 \%$ stated that the opportunity to make quick sale without overhead cost is the main attraction. About $35 \%$ of the respondents claimed ownership of retail space (shop) which they use for storage because they were not getting enough patronage at the retail space (Adeagbo [20]).

Table 1: Reasons for involvement.

\begin{tabular}{lccccccccc}
\hline \multicolumn{1}{c}{ Street name } & $\mathrm{U}$ & $\%$ & $\mathrm{PO}$ & $\%$ & $\mathrm{HR}$ & $\%$ & $\mathrm{QS}$ & $\%$ & Total \\
\hline Old Garage & 49 & 40.2 & 2 & 1.6 & 7 & 5.7 & 64 & 52.5 & 122 \\
Station road & 26 & 31.7 & 1 & 1.2 & 17 & 20.7 & 38 & 46.3 & 82 \\
Igbonna road & 8 & 29.6 & 0 & 0.0 & 5 & 18.5 & 14 & 51.9 & 27 \\
Olaiya road & 2 & 20.0 & 0 & 0.0 & 6 & 60.0 & 2 & 20.0 & 10 \\
Oke-Baale & 2 & 8.7 & 2 & 8.7 & 10 & 43.0 & 9 & 39.1 & 23 \\
Oja-Oba & 2 & 14.3 & 1 & 7.1 & 6 & 42.9 & 5 & 35.7 & 14 \\
Total & 89 & 32.0 & 6 & 2.2 & 51 & 18.3 & 132 & 47.5 & 278 \\
\hline
\end{tabular}

U - Unemployment, PO - Primary Occupation, HR - High Rent, QS - Quick Sale (Source: field survey, 2014.)

\subsection{Articles sold}

The articles displayed along road-sides, pavements or road median, in temporary structures, on wheel barrow by traders are varied. They are categorized into foodstuffs, electronics, shoes/bags, clothing materials, stationeries and household devices. Old Garage area features the highest collection of items because it is the main central business district of the town and features the highest concentration of business concerns, and highest vehicular and pedestrian traffic. 


\subsection{Length of engagement and choice of location}

Table 2 shows that more than half of the respondents have been engaged in the activity for two to five years, $25.2 \%$ of the respondents claimed to have spent 6 10 years, while $21.2 \%$ indicated that they were just less than a year. An insignificant $0.7 \%$ reported they have been in the business for more than 11 years.

On a descending scale, respondents reported the reason for their choice of location as patronage $(67.3 \%)$, centrality $(16.2 \%)$, transport cost $(9.7 \%)$ and accessibility (5\%). It is clear and makes economic sense that the overriding reason for choice of location is patronage which is a function of income and profit.

Table 2: Duration of engagement.

\begin{tabular}{|lccccccccc|}
\hline Street name & $\mathbf{1 y r}$ & $\mathbf{\%}$ & $\mathbf{2 - 5 y r s}$ & $\mathbf{\%}$ & $\mathbf{6 - 1 0 y r s}$ & $\mathbf{\%}$ & $>\mathbf{1 0 y r s}$ & $\mathbf{\%}$ & Total \\
\hline Old Garage & 12 & 9.9 & 67 & 55.4 & 40 & 33.1 & 2 & 1.7 & 121 \\
Station road & 22 & 28.8 & 45 & 54.9 & 15 & 18.3 & 0 & 0 & 82 \\
Igbonna road & 8 & 29.6 & 14 & 51.9 & 5 & 18.5 & 0 & 0 & 27 \\
Olaiya road & 5 & 50 & 4 & 40 & 1 & 10 & 0 & 0 & 10 \\
Oke-Baale & 8 & 34.8 & 9 & 39.1 & 6 & 26.1 & 0 & 0 & 23 \\
Oja-Oba & 4 & 26.7 & 7 & 46.7 & 3 & 20 & 1 & 6.7 & 15 \\
Total & $\mathbf{5 9}$ & $\mathbf{2 1 . 2}$ & $\mathbf{1 4 6}$ & $\mathbf{5 2 . 5}$ & $\mathbf{7 0}$ & $\mathbf{2 5 . 2}$ & $\mathbf{3}$ & $\mathbf{1 . 1}$ & $\mathbf{2 7 8}$ \\
\hline
\end{tabular}

Source: field survey, 2014.

\subsection{Profit of per day}

Businesses are carried out with the ultimate end of making profit. In other words, profit to a large extent determines the sustainability of the business. Table 1 has shown that the overriding factor in street trading activity is financial reward just like every other business activity. Table 3 reveals an interesting scenario; the highest average profit was reported in Old Garage which is the central business district of Osogbo and which generates the highest traffic of vehicles and pedestrians. This also confirms the assertion that street traders are attracted to locations where they could get high profit. Station road, Oke Baale, Oja Oba and Olaiya areas followed respectively. The calculated average profit per day for all

Table 3: Average profit of respondents per day.

\begin{tabular}{lc}
\hline \multicolumn{1}{c}{ Street } & Profit \\
Old Garage & N 5,135.25 $(\$ 25.81)$ \\
Station road & N 3,923.78 $(\$ 19.71)$ \\
Igbonna road & N 3,305.56 $(\$ 16.61)$ \\
Olaiya road & N 3,500.00 $(\$ 17.59)$ \\
Oke Baale & N 3,858.70 $(\$ 19.39)$ \\
Oja Oba & N 3,785.71 $(\$ 19.02)$ \\
\hline
\end{tabular}

Source: field survey, 2014. 
the sampled population was $\$ 4,367.81$ (about $\$ 22$ ). This is quite significant even though studies show them as low income earners, but their daily profit margin shows that their income is relatively high compared to a civil servant whose minimum wage is $\$ 18,000$ (about \$91) monthly.

\subsection{Payment of tax}

One of the civic responsibilities and obligations of every citizen is to pay tax. $82.4 \%$ of the respondents said they do not pay tax, while $17.6 \%$ claimed to pay tax. A closer examination showed that the traders had varied views of the tax they claim to pay. Some made reference to a mandatory $\$ 50.00$ (\$0.25) daily ticket fee paid to the local government; while others gave varied amount ranging from $\$ 200-\$ 1000$ (\$1-\$5) monthly paid to the owners of property behind where they trade; this in essence guarantee the stay of the traders in these locations. These payments are not really the government tax expected from the traders. In actual fact, they constitute a substantial part of the informal sector that has not been captured in the tax regime of the country.

\subsection{Confrontation by law enforcement agents}

Bhowmik [21] observed that in India, road-side traders conduct their business amidst insecurity. Whenever eviction drives are conducted, their wares are seized or destroyed. In Nigeria, the situation is not different as road-side traders experience all kinds of confrontations from the security agents who have been empowered by legal instruments to seize and confiscate the wares of traders that violate the street trading law [22, 23]. More than half of the respondents $(54.9 \%)$ reported harassment from law enforcement agents several times asking them to vacate the road sides. However, these attempts have always been ineffective as the traders return to the same location to continue their activities.

\subsection{Respondents' awareness of risks involved in street trading}

A significant $84.2 \%$ reported that they were aware of the risks involved in their activities while the remaining $15.8 \%$ rationalised that the risk was worth it. At the street levels, the table reveal very high levels of awareness (between $80 \%$ and 93\%) in Old Garage and Station roads while the other streets recorded between $70 \%$ and $79 \%$ (Figure 2). This is likely to be due to the higher traffic flow of pedestrians and vehicles in Old Garage and Station roads than the other areas. The identified risks are: being hit by vehicles (BHV), loss of goods (LGDS), exposure to high concentration of air pollutants such as vehicle exhaust (EHCP), exposure to hot sun and inclement weather (ESIW), crime and theft (CRMT), sexual harassment (SXH) and kidnapping (KDNP).

\subsection{Problems traders cause as a result of their location}

Apart from difficulties that street traders encounter, they also constitute challenges to the traffic flow, the pedestrians and the immediate environment. Some of the problems identified manifests in the form of traffic congestion occasioned by the reduction of the effective road space (see figure 4(a) and (b)), 
waste management, unhealthy competition over customers and accidents. 52.5\% of the problems created are related to traffic congestion; followed by $34 \%$ accidents; $7.8 \%$ are of unhealthy competition amongst themselves while $5.7 \%$ are waste generation and poor sanitary environments. The waste generated by the activities of street traders defaces the street and clog drainages.

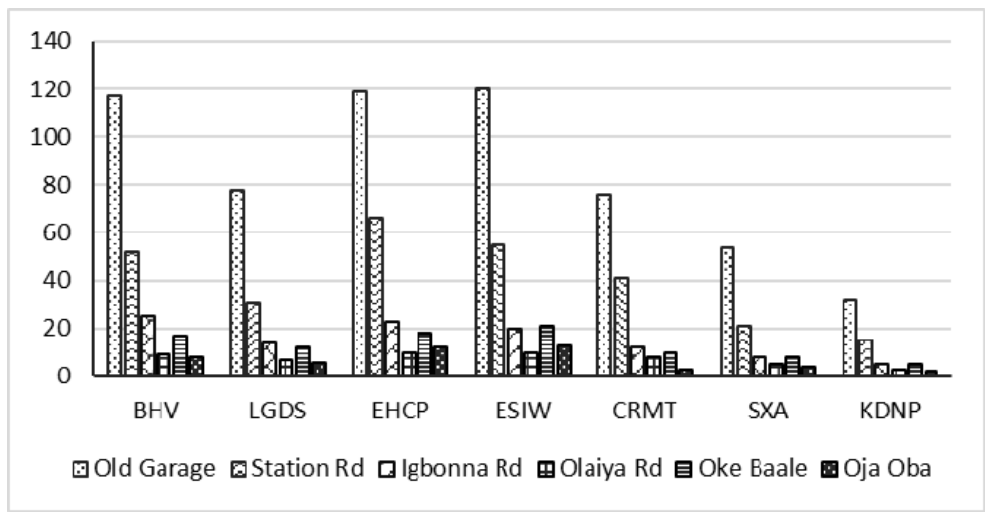

Figure 2: Levels of risk awareness.

It was observed from the study that road-side trading causes traffic congestion based on the responses of other road users. McGee [24] observed that street trading causes traffic congestion because traders congregate at points along the roads where pedestrian and vehicular traffic is heavy. The issue of traffic congestion can also be attributed to the narrowing of the width of traffic lanes due to structures put there by the traders. The practice of road-side trading also poses problems of hygiene and sanitation because, traders dealing in food items usually expose them to flies and displays them under unsanitary conditions. Closely related to this is the unkempt nature of the environment in which they carry out their trading activities.

\section{Summary of findings}

The study revealed that variation exists in the socio-demographic characteristics of the road-side traders. Based on the sample studied, there are more males than females. The sample is dominated by persons within the age group of 18-45 years recording $74.5 \%$ of the entire respondents. This implies that the activity is undertaken by the productive agile young men and women in their prime. Men dominate in the trading activity because men are more suited for running after vehicles, crisscrossing the road in heavy traffic and bracing the odds of the weather.

The study also revealed that a significant proportion of the street traders became involved in order to meet-up with their economic inadequacy as only $32 \%$ of the respondents reported unemployment as the reason for their involvement while $2.2 \%$ reported that the activity is their primary occupation. Others move onto to street sides because they are unable to afford a retail space 


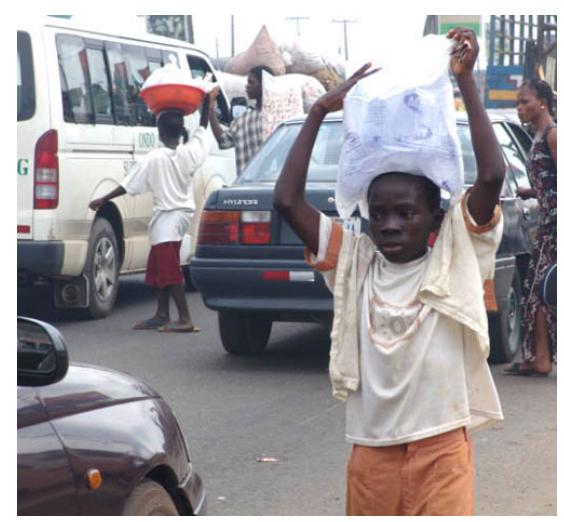

Figure 3: $\begin{aligned} & \text { Street traders vending their merchandise (credit: } \\ & \text { pmnewsnigeria.com) }\end{aligned}$

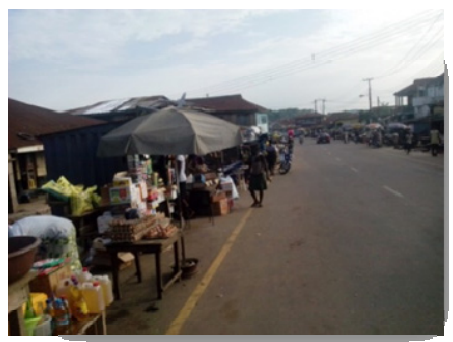

(a)

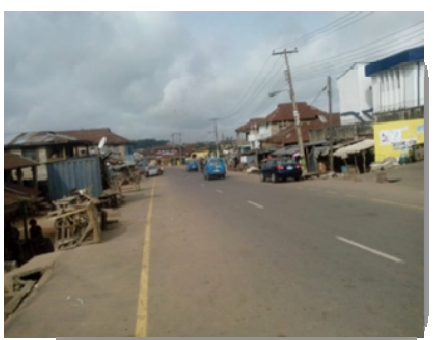

(b)

Figure 4: Oja Oba road (a) before and (b) during trading activities.

while those that could afford it get involved because of low patronage. The study equally revealed that the choice of location made by the traders was mainly based on patronage and they make an average of $\$ 4,367.81$ (about \$22) with a standard deviation of 640.7. The analysis of risk awareness of the respondents revealed that a significant proportion $(84.2 \%)$ were aware of the risks involved in their activities and the most reported risk was exposure to high concentration of air pollutants such as carbon monoxide and dust particles and exposure to the sun and inclement weather.

\section{Conclusion}

In conclusion, this study has revealed that informal trading activities in Osogbo is a consequence of spatial and economic deprivation resulting from unplanned urbanization and inability of existing economic, social and physical structures to meet the rapidly growing demand of urban population. It identifies the effect of roadside trading as traffic hold-up, reduction of effective road space, 
encroachment on road setback, waste management issues, vulnerability to different kinds of risks by the traders and environmental degradation.

\section{Recommendations}

- The street traders should be recognised and integrated into the economic system instead of the current animosity towards them.

- Protection of the traders in the form government sponsored safety regulations for their operations as well as the enforcement of the existing traffic laws and safety measures.

- A comprehensively planned alternative location solely for the road-side traders and with their active participation. Such location should have high connectivity and accessibility in order for the traders to have adequate patronage comparable to the one they have in their present locations.

\section{References}

[1] Skinner, Caroline (2011) AAPS Planning Education Toolkit: The Informal Economy, retrieved from http://wiego.org/resources/aaps-planningeducation-toolkit-informal-economy

[2] Lu, Jinky (2005) Gender, Health and Information Technology. Quezon City, Philippines: University of the Philippines Press, pp. 210-218.

[3] Adeyinka, S.A., Omisore, E.O., Olawumi, P.O. and Abegunde, A.A. (2006) "An Evaluation of Informal Sector Activities and Urban Land Use Management in South Western Nigeria” TS 35 - Informal Settlements: Policy, Land Use and Tenure, Shaping the Change, XXIII FIG Congress, Munich, Germany, October 8-13, 2006.

[4] Simon, P. B. (1998) "Informal Responses to Crisis of Urban Employment: An Investigation into the Structure and Relevance of Small Scale Informal Retailing in Kaduna, Nigeria". Regional Studies 32 (6).

[5] United Nations Department of Public Information (UNDPI) (2008) Achieving the Millennium Development Goals in Africa. Recommendations of the MDG Steering Group. http://www.mdgafrica. org.pdf

[6] Umahi, H, (2008) Hawkers of Death: Watch it; that Street Vendor Could Be Dangerous. The Sun Newspaper, Saturday, September 27, 2008.

[7] Awe, B. and Albert, O. (1995) Historical development of Osogbo. In: Model of Growing African Town. C. O. Adepegba (Ed). Institute of African Studies University of Ibadan, Nigeria.

[8] Disaster Management Institute, (DMI) Bhopal (2016) Concept of Safety. Retrieved from http://www.hrdp-idrm.in/e5783/e17327/e24075/e27336/

[9] Oakes, Charles G. (2009) "Safety versus Security in Fire Protection Planning: The Case of Fire Access Roadways", AIA Knowledge Net, January 2009, http://www.aia.org/practicing/groups/ 
[10] Keating, D.P., \& Halpern-Felsher, B.L. (2008) Adolescent drivers: A developmental perspective on risk, proficiency, and safety. American Journal of Preventive Medicine, 35, 272-277.

[11] Rhodes, T. (1997) Risk theory in epidemic times: Sex, drugs and the social organization of 'risk behavior.' Sociology of Health \& Illness, 19(2), 208227.

[12] Finucane, M.L., Alhakami, A., Slovic, P., \& Johnson, S.M. (2000) The affect heuristic in judgments of risks and benefits. Journal of Behavioral Decision Making, 13, 1-17.

[13] Ajzen, I., \& Fishbein, M. (1980) Understanding attitudes and predicting social behavior. Upper Saddle River, NJ: Prentice-Hall.

[14] Cassim, F. (1982) 'Labour market segmentation: The theoretical case', South African Journal of Economics, 50(4): 240-247.

[15] Habib, A. (2005) 'State-civil society relations in post-apartheid South Africa', Social Research, 72(3): 671-690.

[16] Ogurinola, I. O, Fadayomi, T, Amoo, E. O \& Ola-David, O (2014) Occupational Health and Safety among Street Traders in Nigeria. International Journal of Economics and Finance; Vol. 6, No. 4. pp. 59-68.

[17] Kwankye Stephen O, Nyarko Philomena E. \& Tagoe Cynthia A. (2007) Reproductive Health implications of Street Hawking in Accra. Paper presented at the Fifth African Population Conference organized by Union for African Population Studies, Arusha, Tanzania, 10-14 December 2007.

[18] Mitullah, Winnie V. (2003) Street vending in African cities: a synthesis of empirical findings from Kenya, Cote D'Ivoire, Ghana, Zimbabwe, Uganda, and South Africa. World Development Report background papers; 2005. Washington, DC: World Bank.

[19] Ayeni, O. O. (1980) "Street Trading in Ibadan, Focus on LebanonAmunigun-Feleye Agbeni and Gege Streets". Department of Town Planning and Estate Management. The Polytechnic, Ibadan.

[20] Adeagbo, D. (1997) "Physical and Socio-economic Impact of Street Trading: Case study of Ibadan" NISER Monograph Series No. 10.

[21] Bhowmik, K. S (2003), "Urban Responses to Street Trading: India". Paper for panel entitled "Urban Responses to Street Traders: A Comparative Perspective from India, Kenya and South Africa" at the Urban Research Symposium on Urban Development for Economic Growth and Poverty Reduction, World Bank, Washington, D.C., December 2003.

[22] Daily Independent, Nigerian Newspaper, (2014) Lagos task force warns against roadside trading. http://dailyindependentnig.com/2014/03/lagostask-force-warns-against-roadside-trading/

[23] Ekeanyanwu, O. (2012) The challenges of Abuja street traders - Premium Times Nigeria. Retrieved from http:/www.premiumtimesng.com/news/ 104869-the-challenges-of-abuja-street-traders.html

[24] McGee, T. (1979) "Hawkers in Hong Kong: A Study of Planning in a Third World City" Hong Kong, Centre of Asian Studies, 1974. 